Canadian University Music Review

Revue de musique des universités canadiennes

\title{
Charles Hamm. Putting Popular Music in Its Place. Cambridge: Cambridge University Press, 1995. xii, 390 pp. ISBN 0-521-47198-2 (hardcover)
}

\section{Howard Spring}

Volume 18, numéro 2, 1998

URI : https://id.erudit.org/iderudit/1014663ar

DOI : https://doi.org/10.7202/1014663ar

Aller au sommaire du numéro

Éditeur(s)

Canadian University Music Society / Société de musique des universités canadiennes

ISSN

0710-0353 (imprimé)

2291-2436 (numérique)

Découvrir la revue

Citer ce compte rendu

Spring, H. (1998). Compte rendu de [Charles Hamm. Putting Popular Music in Its Place. Cambridge: Cambridge University Press, 1995. xii, 390 pp. ISBN 0-521-47198-2 (hardcover)]. Canadian University Music Review / Revue de musique des universités canadiennes, 18(2), 115-118.

https://doi.org/10.7202/1014663ar

All Rights Reserved (C Canadian University Music Society / Société de musique des universités canadiennes, 1998
Ce document est protégé par la loi sur le droit d'auteur. L'utilisation des services d’Érudit (y compris la reproduction) est assujettie à sa politique d'utilisation que vous pouvez consulter en ligne.

https://apropos.erudit.org/fr/usagers/politique-dutilisation/ 
Charles Hamm. Putting Popular Music in Its Place. Cambridge: Cambridge University Press, 1995. xii, 390 pp. ISBN 0-521-47198-2 (hardcover).

The title, "Putting Popular Music in Its Place," is not meant as a put down of popular music but as a pointed summary of what this book does: attend to popular music and "its place in the world" (p. xi). It is a collection of essays that vary widely in scope, purview, purpose, and historical period-from broad postmodern overviews of popular music historiography to detailed studies of particular music makers; from South Africa to China and the United States; from Dvořák to Gershwin, from Elvis Presley to Irving Berlin, from Paul Simon to John Cage.

John Cage?-a name not usually found in the pantheon of popular music icons. But Cage is one of the first who proposed a "proto-postmodern aesthetic" (p. xi), and thereby provided support for the notion that all musical events and musics are worthy of attention. He thus paved the way for the serious study of popular music at a time when it was considered outside the pale of "serious" musicology. Hamm knew and admired Cage and it was Hamm's connection with Cage that set the stage for him to consider popular music as a meaningful field of study.

In the spirit of Cage's approach to music, Hamm included in his research musics that were not considered to be part of the popular music canon. His work on popular music in South Africa and China is a case in point. Today, writing on the popular music of these areas is not so out of the ordinary. But when Hamm wrote his articles, during the late 1970s and early to mid-1980s, serious attention to popular musics outside of the United States, especially by American musicologists, was not common. Even rarer were articles that compared "black" musics in the United States and South Africa in terms of how the musicians in the latter responded to the music of the former ("AfricanAmerican Music, South Africa, and Apartheid," "Home Cooking and American Soul," and "Rock 'N' Roll in a Very Strange Society"). To this day, comparative discussion of this kind is not very widespread. With these articles then, Hamm can be considered a pioneer in the academic study of world popular musics, a field that only now is starting to be accepted in the academy (if we are to judge from courses on this topic that are beginning to appear in university music curricula).

Hamm states in his preface that all of the essays share some common assumptions. The first is that popular music is both an acoustical and a cultural event and therefore the music must be dealt with as well as its social context. Here, Hamm may be responding to the plethora of popular music literature that focuses on cultural and social contexts while giving short shrift to sounds, if not completely ignoring them. Even though he is aware of this shortcoming in other literature on popular music, he is somewhat guilty of it himself. Except for the articles, "If I were a voice': or, the Hutchinson Family and Popular Song as Political and Social Protest" and "A Blues for the Ages," where Hamm discusses Gershwin's use of blues in his Concerto in F, there is not much musical discussion. This is unfortunate since these articles, which focus on 
sounds, are characteristically insightful. More of these kinds of essays would be welcome.

Hamm's second assumption is that "one cannot fully understand the nature of a given musical event unless one is present at it, or can reconstruct it from critical or historical documentation" (p. xii). In this case Hamm lives up to his supposition. Nowhere is this more apparent than when he speaks of the popular music of China and South Africa based as they are on trips he took to these countries. On his visit to China, Hamm spoke to officials of the Central People's Broadcasting Station, listened to hours of radio programmes in six different cities in China, carried on discussions about Chinese popular music with faculty and students at various conservatories, and talked with members of the Chinese Musicians' Association. None of this material had been accessible in the West before Hamm's trip, and precious little of it is available today. As to South Africa, the material is based on three trips that he took during the later 1970s and early to mid-1980s. Again he uses material such as radio broadcasts, interviews with record and radio industry personnel, attendance at live performances, buying records, and the popular press.

The third assumption is that "popular music has never existed in isolation from other types of music and is best considered in terms of its interaction with other genres, most certainly the classical repertory" (p. xii). In fact, he addresses this concern only in two articles. In "A Blues for the Ages" he shows in detail how Gershwin took the musical features of the blues, as they were probably understood by a white New Yorker at that time, and transformed them into a more "serious" and therefore a more lasting form, at least, according to Gershwin. In his essay "Dvořák in America: Nationalism, Racism, and National Race," Hamm argues that Dvořák's use of American "folk" music and his urging of American composers to do the same (especially African-American music) has been misunderstood. For Dvořák, African-American "folk" music meant the plantation songs of Stephen Foster and other American composers and not what contemporary writers took it to mean-rural, anonymously composed, and non-commercial.

Popular music is a notoriously slippery item to try and define. Hamm recognizes this. As he puts it, researchers and commentators on popular music suffer from a "severe handicap: we're not sure what we're talking about" (p. 117). But one feature that seems to tie together those musics which Hamm is willing to call "popular" is their association with mass media. Accordingly, in his discussions of South African popular music ("The Constant Companion of Man': Separate Development, Radio Bantu, and Music" and "Privileging the Moment of Reception: Radio and Music in South Africa") and Chinese popular music ("Music and Radio in the People's Republic of China") he makes great use of evidence provided by the radio industry. These articles are a good illustration of how patterns of production and reception and the state's use of popular music on the radio can tell us a lot about how popular music functions in the political arena.

Television, perhaps the most "massive" of the mass media, is too often ignored in the study of popular music. Hamm gives it its due in "Some Thoughts 
on the Measurement of Popularity in Music." In this chapter, popular music research is taken to task for not looking at all the media, especially television, in the analysis of popular musical life. Hamm outlines the resources, problems, and possible conclusions if one were actually to do this. Although originally delivered in 1981, the criticism is still valid. This essay was also written in part to address the problem of how popular music is defined. Although Hamm does not himself provide a definition, the article refines the question by addressing problems of method and evidence.

Hamm's discussion of wide ranging concepts and issues as they apply to the study of popular music is lucid and convincing. The first essay, "Modernist Narratives and Popular Music," is an overview of the various kinds of stories, shaped by modernist thinking, written about the history of popular music. "Towards a New Reading of Gershwin" is compelling as an illustration of how modernism has shaped our perception of history and how an awareness of that can lead us to a new view of that history. It provides a critical reading of the typical perception of Gershwin as a rather conservative force in the world of concert music-at best, a writer of "popular classical music, and classic popular pieces" (p. 307). Hamm recasts Gershwin as a leader in the new era of mass media, that is, in the forefront of the musical life of the twentieth century in that he tried to free music from "modernist form and function" (p. 306).

The meaning of genre and its relationship to context, style, and performance is considered in "Genre, Performance, and Ideology in the Early Work of Irving Berlin." In this essay, Hamm claims that the meaning of a piece can change from performance to performance. In the early work of Irving Berlin, the performer "shapes, reinforces, and even changes genre" (p. 379). This happens because in Berlin's repertory the genre can be determined by the audience's perception of the song's meaning which is shaped, in turn, by the performers delivery.

The relationship between changes in social and cultural history and musical practices is examined in two of the essays. In "Rock and the Facts of Life," Hamm is responding to S. I. Hayakawa's article, "Popular Songs and the Facts of Life," in which he says that popular music does not address "real" life as does, say, the blues. ${ }^{1}$ Hamm refutes this by way of the popular music of the the 1960s. He agrees with Hayakawa that the music of the 1920s, 1930s, 1940s, and 1950s, with its concern with idealized romantic love, gave a distorted view of reality. But by the 1960 s the concerns of youth had changed dramatically to more political and social concerns. Hamm argues that popular music played an important part in this change. In a wide ranging article called "Changing Patterns in Society and Music," Hamm addresses the relationship between society and music again. Citing changes and key events in politics, science, literature, painting, sociology, film, ecology, and comedy since World War II, Hamm accounts for the changes in musical life during the same period as both a response to, and a shaper of these changes.

1S. I. Hayakawa, "Popular Songs vs. the Facts of Life," Etc.12 (1955): 83-95; reprinted in Mass Culture: The Popular Arts in America, ed. Bernard Rosenberg and David Manning White (New York: The Free Press, 1957), 393-403. 
Hamm is as adept at painting finely rendered miniatures as he is at using broad strokes to render a vast panorama. He takes a close look at the particulars of the reception of Lionel Ritchie's "All Night Long" in South Africa ("Privileging the Moment of Reception: Music and Radio in South Africa"). A specific instance of a song's reception in a specific historical setting is used in order to get at its meaning. Meaning is not to be found in the piece as such but rather at the point of reception, informed by the listener's knowledge and competence in deciphering the music.

Hamm focuses on the particular again in "The Last Minstrel Show?" in which he takes a close look at a local minstrel show. Although minstrelsy was in its heyday during the latter part of the nineteenth century, it survived until recently in the town of Tunbridge, Vermont. Hamm investigates this curiosity and considers how the meaning of this show changed over the years for the people.

Each essay in Putting Popular Music in Its Place is introduced with comments, some of them quite long, that provide a context. He includes in these comments some or all of the following: an explanation of the social, political, and historical circumstances of the research; the reception of the paper; the motivation for the writing the paper in the first place; how it fit into musicological discourse and the literature of popular music studies at the time it was written; his own criticisms of the work at hand; and a brief statement of what the article is about, or the purpose of the article. These remarks serve to give the reader a better understanding of what he was trying to do in each of the essays and to bring them up to date when required.

Hamm's style is mercifully free of the jargon that one can encounter in the popular music literature, especially those who take a postmodernist approach to their subject. His writing is clear and direct. But there seems to be little to bind all of the essays together; one searches in vain for an overarching theme that might tie the book-for example, Hamm's own theory of popular music and society. Perhaps there needn't be one in a book that is a compilation of essays that cover such diverse geographic and historical topics.

I highly recommend this book for anyone interested in popular music studies. It provides useful data as well as original approaches. Aside from the many interesting things that Hamm teaches us in each of these essays, this book is valuable because it acts as an example of the kind of high standards in scholarship that we should all strive to match. 